\title{
Pembelajaran Daring dan Kebijakan New Normal Pemerintah
}

\author{
Rifa Afiva Firyal \\ Program Studi Pendidikan IPS, FKIP Universitas Lambung Mangkurat \\ Rifaafiva@gmail.com
}

\begin{abstract}
Abstrak:
Pendidikan saat ini menjadi dasar dari kemajuan pembangunan generasi bangsa. Indonesia juga sedang menghadapi wabah pandemi Covid-19 maka pemerintah menerapkan kebijakan pembelajaran secara daring atau dirumah saja dimana peserta didik diharuskan belajar di rumah untuk menghindari terpaparnya Covid-19. Banyak hambatan dan rintangan dalam melaksanakan pembelajaran jarak jauh. Pemerintah menggulirkan wacana "New Normal" termasuk juga ke dalam bidang pendidikan. Tujuan dalam tulisan ini untuk memberikan inspirasi terhadap guru dalam menerapkan model pembelajaran daring dengan tujuan peserta didik tetap mendapatkan pendidikan yang berkualitas. Untuk penerapannya maka diperlukan pembelajaran yang bervariasi dan inovatif supaya peserta didik tetap bersemangat dalam belajar walaupun dilakukan secara daring ini. Pembelajaran daring dapat dilakukan dengan cara pemberian materi kepada peserta didik dalam bentuk video, powerpoint, google meet, google classroom, dll. Kelebihan pembelajaran daring ini juga bisa menjadikan peserta didik lebih efektif dalam belajar karena pembelajaran tidak lelah, menyenangkan, pengalaman baru serta kelemahan pembelajaran daring ini dari koneksi internet yang kurang baik, terkadang peserta didik juga kurang paham dengan materi, terkadang merasa bosan karna tidak bisa berdiskusi dengan teman seperti biasanya. Berdasarkan dari masalah tersebut maka kebijakan pembelajaran daring haruslah menarik dan bervariasi agar memberikan manfaat bagi generasi masa depan bangsa Indonesia dalam pembelajaran.
\end{abstract}

Kata Kunci: Pembelajaran Daring, Covid-19, New Normal.

\section{PENDAHULUAN}

Pembelajaran yang dilakukan tenaga pendidik merupakan bekal bagi peserta didik diberikan yang terbaik agar ketercapaian pendidikan dan pembelajaran yang bermakna. Tenaga pendidik memegang peranan kunci utama keberhasilan untuk dapat menghasilkan generasi emas Indonesia tahun 2045 yang bermutu dan berkualitas seperti yang telah direncanakan. Oleh karena, itu tenaga pendidik harus kompeten dan harus mempunyai kemampuan dalam mendesain dan merencanakan pembelajaran yang bermakna dan bermanfaat untuk perkembangan pengetahuan peserta didik.

Negara kita saat ini sedang menghadapi pandemi virus Covid-19 dan juga saat ini pemerintah menerapkan kebijakan new normal yang implikasinya berpengaruh terhadap sektor pendidikan sehingga peserta didik diminta untuk belajar di rumah demi menghindari terpaparnya Covid-19. Tenaga pendidik dan peserta didik diharuskan melakukan pembelajaran secara daring sehingga tidak terjadi tatap muka di kelas seperti biasanya, tentu kejadian seperti 
ini menuntut peserta didik dan juga tenaga pendidik harus belajar dan melakukan pembelajaran secara daring atau jarak jauh tetapi dengan ketercapaian dan tujuan pendidikan yang tetap berkualitas dan bermutu.

Ketika COVID-19 mewabah hingga ke Indonesia dan memuncak pada Maret 2020, pemerintah mengeluarkan kebijakan WFH (work from home) agar virus ini tidak menyebar secara massif. Respons dunia pendidikan adalah belajar secara online atau daring. Sekolah dan kampus semua 'diliburkan' alias beralih belajar di kampus ke rumah sebagai konsekuensi kebijakan WFH sehingga social and fisical distancing dapat berjalan untuk mengurangi penyebaran virus (Syaharuddin, S. (2020).

Proses pembelajaran dalam bidang pendidikan harus terus berlangsung meski saat ini tengah terjadi pandemi Covid-19 tetapi kebijakan new normal dan kebijakan pemerintah terhadap pendidikan secara daring tetap dilaksanakan agar generasi emas tidak ketinggalan pengetahuan dalam belajar dan tetap melakukan pembelajaran demi kemajuan generasi penerus sebagai tunas kemajuan bangsa di masa mendatang. Kenapa jadi dilakukannya pembelajaran di rumah saja agar mengurangi siklus penyebaran Covid-19 dari lingkungan sekolah maupun kelas.

Pada penerapan pembelajaran daring ini tidak lepas dengan penggunaan elektronik seperti telepon genggam, tablet, atau laptop dan juga koneksi internet Wi-fi maupun jaringan seluler sendiri yang dimanfaatkan sebagai bagian dari kegiatan pembelajaran. Teknologi merupakan hal yang terpenting dalam pembelajaran daring, teknologi tersebut diantara-Nya bisa berupa smartphone, laptop dan benda pendukung lainnya. Smartphone gadget adalah hal yang paling umum digunakan peserta didik daripada laptop, karena lebih praktis dan banyak fitur canggih (Subiyakto, B., Susanto, H.. \& Akmal, H.. 2019).

\section{PEMBAHASAN}

Di tengah pandemi COVID-19 ini tentu sangat tidak mungkin untuk menerapkan pembelajaran tatap muka namun setidaknya bisa dilakukan secara daring melalui berbagai platform aplikasi yang tersedia seperti Zoom, Google Meet, Google Classroom merupakan media yang dapat dioptimalkan. Melalui media aplikasi elektronik tersebut tenaga pendidik dapat mentransfer pengetahuan dan keterampilan dalam pembelajaran. Selain memakai aplikasi khas untuk kegiatan pembelajaran, guru dan peserta didik juga biasanya menggunakan aplikasi WhatsApp karena dinilai lebih mudah. 
Dari sekian daftar aplikasi yang sudah disebutkan, aplikasi WhatsApp lah yang penggunaannya lebih mudah diakses hingga ke pelosok desa, asal jaringan internetnya ada maka aplikasi ini tidak memerlukan loading yang lamban dan tidak memakan banyak kuota. Peran tenaga pendidik tentu tidak tergantikan oleh mesin (teknologi), tetapi kemampuan tenaga pendidik menyentuh pada aspek rasa, bahasa dan pembentuk karakter menjadikan kehadirannya selalu ditunggu oleh peserta didik, kapan pun dan dimanapun.

Teknologi tentu diciptakan untuk memudahkan pekerjaan manusia, termasuk dalam proses pembelajar, perpaduan kedua hal ini merupakan solusi yang tepat dalam belajar dimasa sekarang khususnya saat penerapan kebijakan new normal saat ini. Oleh sebab itu, proses penerapan pembelajaran ini sangat berpengaruh terhadap pemahaman peserta didik ketika memahami materi dalam lingkup kelas daring. Selain itu juga kurikulum pendidikan harus disesuaikan dengan situasi pandemi saat ini. Seperti, menerapkan protokol kesehatan dengan menerapkan social distancing (Jaga jarak). Sehingga, para pendidik dan peserta didik juga akan merasa nyaman ketika proses pembelajaran berlangsung. Saya sebagai mahasiswa harus bisa beradaptasi dengan kondisi saat ini. Menurut sudut pandang saya sebagai seorang mahasiswi dengan kondisi sekarang kita jadi lebih dapat menikmati waktu bersama keluarga. Saya juga menyarankan agar situasi saat ini harus dimanfaatkan dengan hal-hal yang produktif serta positif seperti, mengikuti seminar, lomba karya tulis dan lain sebagainya.

Oleh karena itu, saya berharap semoga pemerintah dapat memaksimalkan perencanaan pendidikan dengan baik di tengah pandemi Covid-19 yang masih belum berakhir. Kesigapan Pendidikan Di Tengah New Normal mulai dari peraturan kebijakan dan aturan protokol kesehatan tetap di terapkan sampai pandemi berakhir. Oleh karena itu, dengan menerapkan pola hidup sehat di era new normal ini adalah kata kunci untuk selalu menjaga kesehatan dan pola hidup yang baik.

Di masa new normal ini dunia pendidikan harus memanfaatkan teknologi untuk menunjang efektivitas pembelajaran. Mengingat, empat bulan terakhir ini kita masih menggunakan sistem pembelajaran daring. Tentunya ini menimbulkan reaksi dari berbagai pihak, terkhusus, pihak orang tua peserta didik. Kekhawatiran dan kecemasan akan menjadi kendala bagi siswa untuk belajar. Kita tahu, bahwa hingga sampai hari ini kasus penyebaran Covid-19 di Indonesia masih belum berhenti. Oleh karena itu, kebijakan tersebut perlu di pertimbangkan oleh berbagai pihak. Setidaknya dalam proses pembelajaran dibuka kembali telah memenuhi syarat protokol kesehatan Covid-19.

Walaupun pembelajaran dilakukan secara daring, pengajar tetap harus memasukkan kearifan lokal dalam pembelajaran. Penggunaan sumber belajar berbasis lokal membantu siswa 
untuk melihat contoh kontekstual (Wahyuningsih, S., Abbas, E. W., \& Mutiani, M. (2020). Selain itu nasib peserta didik yang bertempat tinggal di daerah pelosok juga dikhawatirkan, karena fasilitas jaringan internet yang kurang memadai daya jangkaunya, sinyal yang kurang, uang buat membeli kuota, juga tingkat pemahaman peserta didik masih rendah tentang penggunaan aplikasi belajar secara daring.

Sumber belajar pembelajaran sosial diekstraksi dari konten lokal memiliki potensi untuk membuat belajar lebih bermakna bagi siswa. Pembelajaran yang bermakna, dalam hal ini, adalah bahwa materi yang disajikan tidak jauh dari sosial budaya lingkungan siswa (Syaharuddin, S., Arbainah, A., \& Mutiani, M. (2020).

karena di dalam kearifan lokal terdapat nilai-nilai yang bagus untuk dijadikan sumber belajar terutama sumber belajar IPS. Nilai merupakan segala sesuatu yang dianggap berharga, penting dan diakui oleh masyarakat yang dapat menjadi patokan dalam berperilaku di kehidupan sehari-hari. Nilai tersebut dipengaruhi oleh etika, kepercayaan, maupun agama yang mempengaruhi sikap dan pandangan individu yang kemudian tercermin dalam cara bertindak dalam memberikan penilaian (Syaharuddin, S., Hidayat Putra, M. A., \& Susanto, H. (2019). perlu diingat tujuan utama pendidikan adalah untuk menanam nilai-nilai yang baik bagi peserta didik.

Sumber belajar pembelajaran sosial harus dilihat sebagai kesatuan yang utuh dalam proses pembelajaran. Sebagai kesimpulan, sumber belajar pembelajaran sosial praktis dan efektif dalam jiwa dan tindakan manusia dan secara objektif dilembagakan dalam masyarakat. Kontribusi nilai-nilai pendidikan dan sumber belajar pembelajaran sosial adalah suatu bentuk integrasi nilai pendidikan dalam pembelajaran sosial (Subiyakto, B., \& Mutiani, M. (2019).

Di antara kelemahan teknologi-guru mesin adalah tidak memiliki rasa, bahasa dan karakter. Namun, hanya berperan sebagai transfer of knowledge. Karena itu, peran ini harus menjadi milik guru sebagai pendidik yang tidak hanya menjalankan fungsi transfer ilmu pengetahuan (transfer of knowledge) tapi juga mampu membentuk sikap dan perilaku (transfer of values) sebagai tugas utama guru, khususnya pada jenjang pendidikan dasar dan menegah. (Syaharuddin, S. (2020).

Teknologi memiliki peran yang sangat penting terutama bagi dunia pendidikan. Pendidikan tanpa memanfaatkan teknologi informasi akan menjadi lemah terutama di bidang mutunya, apalagi di tengah pandemi Covid-19. Akibat dari Covid-19 semua kegiatan dilakukan di rumah seperti bekerja dirumah, beraktivitas dirumah, dan kegiatan belajar mengajar pun yang harusnya dilakukan disekolah kini dilakukan secara daring. 


\section{SIMPULAN}

Tatanan new normal merupakan transformasi perilaku hidup di masyarakat untuk tetap menjalankan aktivitas normal namun dengan menerapkan protokol kesehatan sampai ditemukannya vaksin yang dapat menyembuhkan para korban yang terinfeksi Covid-19. kebijakan tersebut perlu di pertimbangkan oleh berbagai pihak. Setidaknya dalam proses pembelajaran dibuka kembali telah memenuhi syarat protokol kesehatan covid-19.

Teknologi tentu diciptakan untuk memudahkan pekerjaan manusia, termasuk dalam proses pembelajar, perpaduan kedua hal ini merupakan solusi yang tepat dalam belajar dimasa sekarang khususnya saat penerapan kebijakan new normal saat ini. Oleh sebab itu, proses penerapan pembelajaran ini sangat berpengaruh terhadap pemahaman peserta didik ketika memahami materi dalam lingkup kelas daring. 


\section{DAFTAR PUSTAKA}

Abbas, E. W. (Ed.). (2017). Membangun pendidikan. Fakultas Keguruan dan Ilmu Pendidikan, Universitas Lambung Mangkurat.Syaharuddin, S. (2020). PEMBELAJARAN MASA PANDEMI: DARI KONVENSIONAL KE DARING. PEMBELAJARAN MASA PANDEMI: DARI KONVENSIONAL KE DARING.

Abbas, E. W. (2018). Penguatan Pendidikan IPS Di Tengah Isu-Isu Global.

Abbas, E. W., Hidayat Putra, M. A., \& Noor Handy, M. R. (2019). Laporan Penelitian: PEMANFAATAN EKOWISATA SUNGAI MARTAPURA KOTA BANJARMASIN SEBAGAI SUMBER BELAJAR IPS.Subiyakto, B., \& Akmal, H. (2020). Profesi Keguruan.

Hasanah, M., ABBAS, E. W., Subiyakto, B., Fikriah, N., \& Syahrin, M. A. (2017). Implementasi Pembelajaran IPS yang Berbasis Kearifan Lokal di SMPN 1 Gambut Kabupaten Banjar. Implementasi Pembelajaran IPS yang Berbasis Kearifan Lokal di SMPN 1 Gambut Kabupaten Banjar.

Mutiani, M., Abbas, E. W., Syaharuddin, S., \& Susanto, H. Membangun Komunitas Belajar Melalui Lesson Study Model Transcript Based Learning Analysis (TBLA) dalam Pembelajaran Sejarah. Historia: Jurnal Pendidik dan Peneliti Sejarah, 3(2), 113-122.

Mutiani, M. (2019). INTERNALISASI NILAI PENDIDIKAN MELALUI AKTIVITAS MASYARAKAT SEBAGAI SUMBER BELAJAR ILMU PENGETAHUAN SOSIAL. INTERNALISASI NILAI PENDIDIKAN MELALUI AKTIVITAS MASYARAKAT SEBAGAI SUMBER BELAJAR ILMU PENGETAHUAN SOSIAL.

Syaharuddin, S., Rahman, A. M., \& Fitriyani, R. (2020). Utilization Of Social Community as Learning Resources On Social Studies. The Kalimantan Social Studies Journal, 1 (1), $18-24$.

Syaharuddin, S., Rahman, A. M., \& Fitriyani, R. (2019). Utilization Of Social Community as Learning Resources On Social Studies. The Kalimantan Social Studies Journal, 1(1), $18-24$.

Syaharuddin, S. (2020). Menimbang Peran Teknologi dan Guru dalam Pembelajaran di Era COVID-19. Menimbang Peran Teknologi dan Guru dalam Pembelajaran di Era COVID-19.

Syaharuddin, S., \& Mutiani, M. (2020). STRATEGI PEMBELAJARAN IPS: Konsep dan Aplikasi.

Subiyakto, B., \& Abbas, E. W. (2020). Strategi Pembelajaran IPS: Konsep dan Aplikasi.Subiyakto, B., \& Abbas, E. W. (2020). Strategi Pembelajaran IPS: Konsep dan Aplikasi.

Subiyakto, B., \& Mutiani, M. (2019). Internalisasi nilai pendidikan melalui aktivitas masyarakat sebagai sumber belajar ilmu pengetahuan sosial. Khazanah: Jurnal Studi Islam dan Humaniora, 17(1), 137-166.

Subiyakto. B.. Susanto, H., \& Akmal, H. (2019). Media Pembelajaran Sejarah Era Teknologi Informasi. Banjarmasin: Program Studi Pendidikan Sejarah, ULM.

Susanto, H., \& Akmal, H. (2018). Efektivitas Penggunaan Aplikasi Pembelajaran Berbasis Mobile Smartphone Sebagai Media Pengenalan Sejarah Lokal Masa Revolusi Fisik Di 
Kalimantan Selatan Pada Siswa Sekolah Menengah Atas. HISTORIA: Jurnal Program Studi Pendidikan Sejarah, 6(2), 197-206.

Susanto, H., \& Akmal, H. (2019). Media Pembelajaran Sejarah Era Teknologi Informasi (Konsep Dasar, Prinsi Aplikatif, dan Perancangannya).

Subiyakto, B. (2019). Media Pembelajaran Sejarah Era Teknologi Informasi.

Wahyuningsih, S., Abbas, E. W., \& Mutiani, M. (2020). Implementation of Leadership Value of Rudy Resnawan as a Learning Resources on Social Studies. The Innovation of Social Studies Journal, 1(2), 169-177. 